\title{
NILAI BUDAYA DALAM CERITA LEGENDA DESA TUMIJAYA KECAMATAN JAYAPURA KABUPATEN OKU TIMUR
}

\author{
Syaiful Anam ${ }^{1 *}$, Sugiarti $^{2}$, Shakti Apdilah Pratama ${ }^{3}$ \\ Program Studi Pendidikan Bahasa dan Sastra Indonesia \\ STKIP Nurul Huda OKU Timur \\ syaiful@stkipnurulhuda.ac.id \\ giarti@stkipnurulhuda.ac.id \\ shakti@stkipnurulhuda.ac.id
}

\begin{abstract}
Abstrak
Tujuan penelitian ini untuk mendeskripsikan nilai-nilai budaya yang terdapat dalam cerita rakyat legenda terbentuknya Desa Tumijaya, Kecamatan Jayapura Kabupaten OKU Timur. Metode yang digunakan adalah metode kualitatif yang bersifat deskriptif dengan teknik penelitian lapangan. Hasil yang diperoleh adalah ditemukannya sembilan nilai budaya dalam cerita legenda Desa Tumijaya. Nilai budaya tersebut yaitu nilai budaya menghormati orang lain, nilai keberagaman agama, nilai keberagaman suku, nilai menghargai keberagaman bahasa yaitu keberagaman bahasa yang dimiliki oleh penduduk Desa Tumijaya di antaranya ada Bahasa Jawa, Ogan, Komering, dan Batak. Nilai tanggung jawab yaitu kesadaran diri manusia terhadap semua tingkah laku dan perbuatan yang disengaja, nilai kasih sayang, nilai keberanian, nilai cinta tanah air, dan nilai pendidikan.
\end{abstract}

Kata Kunci: Nilai Budaya, Cerita Legenda, Desa Tumijaya

\section{PENDAHULUAN}

Indonesia merupakan satu negara yang terkenal dengan kebinekaannya. Kebinekaan Indonesia menghadirkan ragam budaya yang tersebar di Indonesia. Dari Sabang sampai Merauke, setiap suku yang ada memiliki budaya dan ciri kas masing-masing. Salah satu kebergaman yang ditimbulkan oleh kebinekaan Indonesia adalah bervariasinya karya sastra yang ada di Indonesia. Hal ini terlihat dari setiap daerah atau suku yang memiliki cerita atau sastra daerah masing-masing, baik lisan maupun tulisan. Di Indonesia karya sastra itu sendiri memiliki beberapa periodisasi dengan ciri atau karakteristik yang berbeda-beda.

Sastra lisan adalah yang tumbuh dan berkembang dalam masyarakat merupakan bentuk sastra yang paling lama dan memiliki sejarah perkembangan yang panjang tentunya. Karya sastra ini dikenal dengan sastra lama dan umumnya berupa sastra lisan yang merupakan bagian dari folklor. Sastra adalah khazanah kekayaan budaya. Sastra lisan adalah bagaian dari suatu kebudayaan yang tumbuh dan berkembang di tengah masyarakat dan diwariskan secara turun temurun secara lisan.

Selain itu nilai budaya merupakan akar atau jiwa dari kebudayaan yang dimiliki oleh masyarakat. Tata hidup yang tampak dalam masyarakat adalah cerminan nilai budaya yang terkandung di dalamnya. Nilai-nilai ini keberadaannya berupa pola-pola pemikiran yang tertanam dalam masyarakat pemiliknya. Pola ini membentuk suatu sistem yang abstrak namun memiliki kekuatan secara hukum atau normatif dalam kebudayaan masyarakat pemiliknya. Sikap dan pandangan hidup masyarakat terhadap nilai-nilai yang dianut dalam naskah lisan merupakan kebudayaan karena mencerminkan tindakan kehidupan manusia. Sikap hidup dan pandangan hidup tidak dapat dipisahkan dengan nilai budaya, nilai sosial ekonomi, dan alam sekitar tempat masyarakat tersebut berada. Nilai-nilai keyakianan yang relatif menetap dan pandangan hidup tertentu merupakan unsur-unsur yang melandasi suatu kebudayaan.

Budaya merupakan akal budi atau sesuatu yang sukar diubah karena sudah dilakukan atau diyakini dalam jangka waktu yang lama atau bahkan diwariskan dari turun-temurun. Budaya terbentuk dari banyak unsur yang rumit, termasuk sistem agama, dan politik, adat istiadat, bahasa, pakaian, bangunan, dan karya seni. Nilai budaya merupakan suatu bentuk atau konsep umum yang dijadikan pedoman dan petunjuk di dalam bertingkah laku baik secara individual, kelompok, atau masyarakat secara keseluruhan tentang baik buruk, benar, salah, patut atau tidak patut.

Sedangkan legenda merupakan dasar, pondasi, ataupun tiang dari berbagai hal yang 
menunjang dari segala penjuru pengetahuan. Dengan demikian, legenda mempunyai kedudukan di suatu negara, daerah atau desa. Danandjaja (2002:67) berpendapat bahwa legenda mengandung nilainilai dan fungsi-fungsi yang dapat digali yaitu nilai moral dan nilai estetis. Legenda adalah cerita prosa rakyat yang dianggab benar-benar terjadi biasanya berhubungan dengan tokoh sejarah serta dibumbui dengan keajaiban, kesaktian, dan keistimewaan tokoh (Lisa Krisdayani Sitepu, Maria Natalia Situmorang, Wita Dewi, 2019:58). Selain itu, masyarakat yakin bahwa legenda-legenda pernah terjadi pada masamasa yang lama. Legenda memiliki kandungan nilai-nilai luhur yang bermanfaat bagi kehidupan masyarakat. Mengingat begitu besar makna legenda bagi masyarakat pendukungnya, maka perlu diadakan suatu kajian mengenai legenda-legenda yang masih dikenal dan hidup pada masyarakat tertentu. Berdasarkan uraian di atas, penelitian bertujuan untuk mendeskripsikan seperti apa nilai budaya dalam legenda Desa Tumijaya Kecamatan Jayapura Kabupaten OKU Timur.

\section{METODE PENELITIAN}

Metode Peneltian dalam kamus besar bahasa Indonesia adalah cara yang teratur dan terpikir baik-baik untuk mencapai maksud. Sementara itu, metode dalam penelitian ini adalah metode kualitatif. Metode merupakan suatu alat dalam pelaksanaan pendidikan, yang digunakan dalam menyampaikan materi (Maesaroh, 2013:155). Metode penelitian kualitatif sebagaimana yang diungkapkan Sugiyono (2008:15) adalah metode penelitian yang berlandaskan pada filsafat post positivisme yang biasanya digunakan untuk meneliti pada kondisi objektif yang alamiah di mana peneliti berperan sebagai instrumen kunci.

Metode kualitatif yang dipakai dalam penelitian ini, sebagaimana yang diungkapkan oleh Sugiyono (2018:13) Metode kualitatif untuk mendapatkan data yang mendalam, suatu data yang mengandung makna. Metode kualitatif secara signifikan dapat mempengaruhi substansai penelitian.Artinya bahwa metode kualitatif menyajikan secara langsung hakikat hubungan antar peneliti dan informan, objek dan subjek penelitian. Penggunaan metode tersebut karena terkait dengan tujuan penelitian yang akan menggambarkan atau mendeskripsikan objek penelitian berdasarkan fakta yang tampak seperti apa adanya. Tujuan utamanya adalah penggambaran secara obyektif terhadap permasalahan. Proses pendeskripsiannya ditempuh dengan tahapan pengumpulan data, pengklasifikasian masalah, analisis data, dan pengolahan data akhir.

Pendekatan penelitian ini menggunakan pendekatan etnografi. Spradley (2006:7) menyatakan bahwa etnografi merupakan kegiatan mengamati tingkah laku dan menyelidiki makna tingkah laku. Etnografi melihat berbagai artefak dan objek alam, tetapi lebih dari itu dia juga menyelidiki makna yang diberikan oleh orang-orang terhadap berbagai objek itu. Penelitian ini sangat percaya pada ketertutupan, pengalaman pribadi, dan partisipasi yang mungkin, tidak hanya pengamatan, oleh para peneliti yang terlatih dalam seni etnografi. Para etnografer ini sering bekerja dalam tim yang multidisipliner. Di mana titik fokus penelitiannya dapat meliputi studi intensif budaya dan bahasa, bidang atau domain tunggal, ataupun gabungan metode historis, observasi, dan wawancara.

Penelitian ini adalah penelitian sastra lisan nilai budaya dalam legenda berupa studi pustaka yang bersifat kualitatif. Penelitian ini berpaku pada tempat dan waktu, sehingga penelitian ini dilakukan dengan batas waktu yang ditentukan.Tempat penelitian yang diteliti adalah Desa Tumijaya, sedangkan waktu penelitian dilaksanakan dari bulan Desember-Mei.

Sumber data utama dalam penelitian kualitatif adalah kata-kata dan tindakan, selebihnya adalah data tambahan seperti dokumen dan lain-lain". Sumber data yang digunakan dalam penelitian ini berada di Desa Tumijaya Kecamatan Jayapura Kabupaten OKU Timur. Adapun data yang didapatkan dalam penelitian ini berupa rekaman, tulisan, gambar, ataupun video. Data ini nantinya akan dijadikan bentuk tulisan atau kata-kata bukan angka.

Setelah ditentukan tempat sumber data dan data apa yang akan dicari, maka selanjutnya adalah teknik pengumpulannya. Teknik pengumpulan data pada penelitian ini adalah dengan menggunakan wawancara, observasi, dan studi dokumen. Analisis data adalah proses mencari dan menyusun data secara sistematis data yang diperoleh dari hasil wawancara, catatan lapangan dan dokumentasi, dengan cara mengorganisasikan data ke dalam kategori, menjabarkan ke dalam unit-unit, melakukan sintesa, menyusun ke dalam pola, memilih mana yang penting dan yang akan dipelajari, dan membuat kesimpulan sehingga mudah dipahami oleh diri sendiri maupun orang lain. 


\section{HASIL DAN PEMBAHASAN}

NILAI BUDAYA DALAM CERITA LEGENDA DESA...|41

Hasil

Hasil penelitian adalah proses pengelompokan secara baik tentang informasi suatu data yang didapat dalam penelitian yang berdasarkan fakta melalui usaha pikiran peneliti dalam mengolah dan menganalisis objek atau topik penelitian secara sistematis dan objektif untuk memecahkan suatu persoalan. Paparan data hasil penelitian yakni sebagai berikut.

Tabel 1.1

Nilai Budaya yang Terdapat di Desa Tumijaya

\begin{tabular}{|c|c|c|c|}
\hline No & Nilai Budaya & Temuan & Deskripsi \\
\hline 1. & $\begin{array}{l}\text { Menghormati } \\
\text { orang lain }\end{array}$ & $\begin{array}{l}\text { - Menghormati } \\
\text { jasa orang lain } \\
\text { - Menghormati } \\
\text { orang yang lebih } \\
\text { tua } \\
\text { - Menghormati } \\
\text { orang yang baru } \\
\text { dikenal atau } \\
\text { pendatang }\end{array}$ & $\begin{array}{l}\text {...kata Tumi dipakai sebagai bentuk } \\
\text { penghormatan bagi pemukim pertama } \\
\text { yaitu Mbah Tumi. Mbah Tumi } \\
\text { merupakan penghuni pertama di Desa } \\
\text { Tumijaya. Ditunjuk oleh Bapak Pasirah } \\
\text { Ali untuk menjaga, membuka dan } \\
\text { merawat tanah yang ada di Desa } \\
\text { Tumijaya ini bersama masyarakat } \\
\text { lainnya yang ingin tinggal di desa } \\
\text { tersebut. Kemudian semakin hari } \\
\text { semakin banyak masyarakat yang } \\
\text { datang, Mbah Tumi mengusulkan } \\
\text { kepada Bapak Pasirah Ali untuk } \\
\text { supaya tanah tersebut diminta dari } \\
\text { Busnan Sapei kemudian tanah tersebut } \\
\text { dijadikan sebuah desa sehingga } \\
\text { memisah dari Lengot Jayapura. } \\
\text { Keinginan tersebut diusulkan karena } \\
\text { jarak tempuh bagi masyarakat } \\
\text { kejauhan jika desa tersebut tidak } \\
\text { dimekarkan menjadi dua. }\end{array}$ \\
\hline 2. & $\begin{array}{l}\text { Menghormati } \\
\text { keberagaman } \\
\text { agama lain }\end{array}$ & $\begin{array}{l}\text { - Banyaknya } \\
\text { jumlah agama } \\
\text { - Banyaknya } \\
\text { jumlah tempat } \\
\text { beribadah }\end{array}$ & $\begin{array}{l}\text { “...Penganut kepercayaan di Desa } \\
\text { Tumijaya bukan hanya satu agama } \\
\text { saja melainkan agama lain lebih dari } \\
\text { meskipun mayoritas penduduk Desa } \\
\text { Tumijaya ini adalah pemeluk agama } \\
\text { Islam. Dilihat dari jumlah perkepala } \\
\text { keluarga, pemeluk agama Islam } \\
\text { berjumlah } 1939 \text {, pemeluk agama } \\
\text { Kristiani berjumlah 204, } 7 \text { orang } \\
\text { pemeluk agama Hindu. Sedangkan } \\
\text { tempat peribadatan untuk masjid } \\
\text { sebanyak } 2 \text { buah, mushola sebanyak } 8 \\
\text { buah, dan gereja sebanyak } 3 \text { buah. }\end{array}$ \\
\hline 3. & $\begin{array}{l}\text { Menghormati } \\
\text { keberagaman } \\
\text { suku }\end{array}$ & $\begin{array}{l}\text { - Adanya suku } \\
\text { Jawa } \\
\text { - Adanya suku } \\
\text { Ogan }\end{array}$ & $\begin{array}{l}\text { "...Kemudian jumlah keberagaman } \\
\text { suku, jumlah suku di Desa Tumijaya } \\
\text { lebih dari tiga. Bisa dikatakan kalau } \\
\text { Desa Tumijaya merupakan sebuah } \\
\text { desa dengan keberagaman suku } \\
\text { terbanyak di kecamatan Jayapura. } \\
\text { Suku-suku tersebut di antaranya suku }\end{array}$ \\
\hline
\end{tabular}




\begin{tabular}{|c|c|c|c|}
\hline & & $\begin{array}{l}\text { - Adanya suku } \\
\text { Komering } \\
\text { - Adanya suku } \\
\text { Batak }\end{array}$ & $\begin{array}{l}\text { Jawa, Komering, Batak, dan Ogan. } \\
\text { Meskipun ada suku-suku lainnya, tapi } \\
\text { tak sebanyak suku-suku tersebut. } \\
\text { Tahun } 2017-2018 \text { jumlah suku Jawa } \\
\text { sebanyak } 2089 \text { orang, jumlah suku } \\
\text { Ogan sebanyak } 30 \text { kepala keluarga, } \\
\text { jumlah suku Batak sebanyak } 20 \text { kepala } \\
\text { keluarga, dan Komering sebanyak } 11 \\
\text { kepala keluarga. }\end{array}$ \\
\hline 4. & $\begin{array}{l}\text { Menghormati } \\
\text { keberagaman } \\
\text { bahasa }\end{array}$ & $\begin{array}{l}\text { - Adanya bahasa } \\
\text { Jawa } \\
\text { - Adanya bahasa } \\
\text { Ogan } \\
\text { - Adanya bahasa } \\
\text { Komering } \\
\text { - Adanya bahasa } \\
\text { Batak }\end{array}$ & $\begin{array}{l}\text { "...mayoritas pola komunikasi antar } \\
\text { masyarakat Desa Tumijaya } \\
\text { menggunakan bahasa Jawa. Tetapi } \\
\text { sebenarnya sebagian masyarakat ada } \\
\text { yang mempertahankan bahasa } \\
\text { daerahnya terkhusus ketika berbicara } \\
\text { dengan sesama suku. Bahkan di antara } \\
\text { mereka justru terjadi pertukaran } \\
\text { bahasa, yang orang Jawa belajar } \\
\text { menggunakan bahasa Komering, Ogan, } \\
\text { atau Batak begitupun sebaliknya yang } \\
\text { Komering, Ogan, atau Batak } \\
\text { menggunakan bahasa Jawa atau } \\
\text { lainnya. ini menandakan bahwasannya } \\
\text { ada keharmonisan dalam kehidupan } \\
\text { masyarakat Desa Tumijaya karena mau } \\
\text { membaur dan saling mengenal bahasa } \\
\text { lainnya. Ada sebanyak } 90 \% \text { pengguna } \\
\text { bahasa Jawa, } 3 \% \text { pengguna bahasa } \\
\text { Batak, } 2 \% \text { pengguna bahasa Komering, } \\
\text { dan 5\% pengguna bahasa Ogan. } \\
\text { Dengan demikian memang benar } \\
\text { adanya keragaman bahasa daerah di } \\
\text { desa Tumijaya. }\end{array}$ \\
\hline 5 & $\begin{array}{l}\text { Rasa tanggung } \\
\text { jawab }\end{array}$ & $\begin{array}{l}\text { - Keamanan desa } \\
\text { - Kebersihan desa } \\
\text { - Kemakmuran } \\
\text { desa }\end{array}$ & $\begin{array}{l}\text { "...Namun kondisi Desa Tumijaya ketika } \\
\text { ditinggalkan almarhum Mbah Ramso } \\
\text { sudah berkembang pesat. } \\
\text { Sepeninggalannya jalan-jalan sudah } \\
\text { diperbaiki dan listrik juga sudah } \\
\text { mengalir di rumah-rumah warga. } \\
\text { Masyarakat juga sudah mempunyai hak } \\
\text { tanah kepemilikan untuk bercocok } \\
\text { tanam, desa juga sudah mempunyai } \\
\text { denah peta batas-batas desa. Kini } \\
\text { kepala desa setelahnya tinggal } \\
\text { melanjutkan dari apa yang sudah ada } \\
\text { di zaman almarhum mbah Ramso. }\end{array}$ \\
\hline 6. & $\begin{array}{l}\text { Rasa kasih } \\
\text { sayang }\end{array}$ & $\begin{array}{l}\text { - Keharmonisan } \\
\text { masyarakat } \\
\text { - Kebersamaan } \\
\text { masyarakat }\end{array}$ & $\begin{array}{l}\text { “...Akhirnya disepakatilah nama Desa } \\
\text { Tumijaya tersebut lewat musyawarah } \\
\text { seluruh masyarakat sebagai bentuk } \\
\text { rasa sayang terhadap almarhum, } \\
\text { membuat kebahagiaan serta } \\
\text { kesedihan bagi masyarakat. } \\
\text { Bagaimana tidak, Mbah Tumi yang }\end{array}$ \\
\hline
\end{tabular}


NILAI BUDAYA DALAM CERITA LEGENDA DESA...|43

\begin{tabular}{|c|c|c|c|}
\hline & & $\begin{array}{c}\text { - Kekompakan } \\
\text { masyarakat }\end{array}$ & $\begin{array}{l}\text { akan dilantik menjadi menjadi kepala } \\
\text { desa tiba-tiba hilang tidak diketahui } \\
\text { keberadaannya. Masyarakat mencoba } \\
\text { untuk mencari bersama-sama tetapi } \\
\text { tidak ada hasil dan tidak ditemukannya } \\
\text { almarhum mbah Tumi membuat } \\
\text { masyarakat merasa terpukul. Setelah } \\
\text { itu, masyarakat menduga bahwa } \\
\text { almarhum mbah Tumi diculik oleh } \\
\text { Busnan Sapei. Sejak saat itu, } \\
\text { masyarakat berjanji akan berjuang } \\
\text { baik mati atau hidup akan selalu } \\
\text { bersama-sama. }\end{array}$ \\
\hline 7. & Keberanian & $\begin{array}{l}\text { - Menghadapi } \\
\text { permasalahan } \\
\text { sengketa } \\
\text { - Menyelesaikan } \\
\text { permasalahan } \\
\text { sengketa } \\
\text { - Berani } \\
\text { berpendapat di } \\
\text { depan umum } \\
\text { - Berani berbeda } \\
\text { ketika diminta } \\
\text { solusi }\end{array}$ & $\begin{array}{l}\text { “...Masyarakat Lengot melakukan } \\
\text { pemberontakan terhadap masyarakat } \\
\text { yang tinggal di Tumijaya, berbagai } \\
\text { cara dilakukan. Bapak Busnan dan } \\
\text { putranya serta masyarakat Lengot } \\
\text { lainnya menyerang masyarakat Desa } \\
\text { Tumijaya dengan menggunakan bedil } \\
\text { (senapan) dan mengancam akan } \\
\text { membunuh masyarakat yang tinggal di } \\
\text { Desa Tumi Jaya. Dengan adanya } \\
\text { ancaman tersebut, banyak masyarakat } \\
\text { di Desa Tumijaya ketakutan dan } \\
\text { sebagian memilih untuk mengungsi. } \\
\text { Mbah Tumi pada saat itu bersama } \\
\text { pemuda-pemuda desa seperti Mbah } \\
\text { Ramso, mbah Kusmin, Mbah Gianto, } \\
\text { Bapak Suparni, dan masyarakat } \\
\text { lainnya melakukan mediasi dengan } \\
\text { pihak Bapak Busnan secara baik-baik. } \\
\text { Namun setelah diadakan mediasi } \\
\text { pihak Bapak Busnan tetap tidak mau, } \\
\text { dia mengatakan Desa Tumijaya harus } \\
\text { bergabung dengan wilayah Lengot dan } \\
\text { nantinya dia yang akan memimpin } \\
\text { wilayah tersebut. }\end{array}$ \\
\hline 8. & Cinta tanah air & $\begin{array}{l}\text {-Melakukan segala } \\
\text { upaya demi hak } \\
\text { kepemilikan tanah } \\
\text { sengketa } \\
\text { - Hasil panen yang } \\
\text { melimpah } \\
\text { - Kreatifitas } \\
\text { masyarakat dalam } \\
\text { pemenuhan } \\
\text { kebutuhan }\end{array}$ & $\begin{array}{l}\text { “...Setelah mengetahui syarat-syarat di } \\
\text { antaranya harus mempunyai lahan } \\
\text { sekolahan, harus mempunyai lahan } \\
\text { masjid, harus mempunyai lapangan, } \\
\text { dan jumlah masyarakat tidak boleh } \\
\text { kurang dari } 250 \text { orang. Setelah itu, } \\
\text { syarat-syarat tersebut dicoba untuk } \\
\text { dipenuhi kemudian mbah Tumi dan } \\
\text { lainnya mengajukan proposal untuk } \\
\text { pemekaran. Pada saat itu ternyata } \\
\text { proposal itu lolos di pemerintahan, } \\
\text { kemudian pemerintah meminta Desa } \\
\text { Tumijaya membuat peta dan denah } \\
\text { tanah desa sebelum Desa Tumi ini } \\
\text { nantinya benar-benar mekar dari } \\
\text { kecamatan. Kemudian dimulailah }\end{array}$ \\
\hline
\end{tabular}




\begin{tabular}{|c|c|c|c|}
\hline & & & $\begin{array}{l}\text { pengukuran tanah dan batas desa. } \\
\text { Batas desa disebalah barat adalah } \\
\text { Peracak Jaya, batas timur adalah } \\
\text { Bandarsari, batas utara adalah Kota } \\
\text { Baru Selatan, dan batas selatan yaitu } \\
\text { Jayapura. }\end{array}$ \\
\hline 9. & Pendidikan & 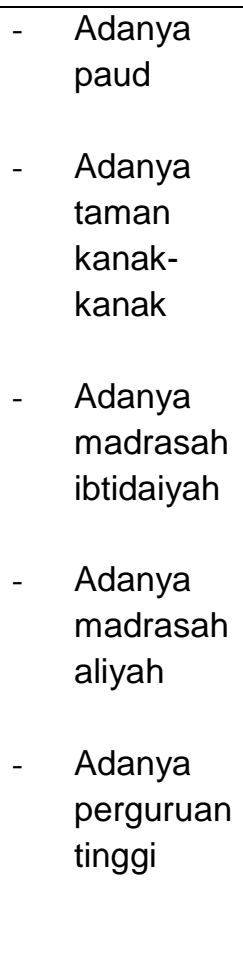 & $\begin{array}{l}\text { “...Selanjutnya jenjang pendidikan di } \\
\text { Desa Tumijaya, jika pada zaman dulu } \\
\text { Desa Tumijaya ini hanya ada } \\
\text { madrasah ibtidaiyah (MI) sekarang } \\
\text { sudah mengalami kemajuan di bidang } \\
\text { pendidikannya. Sekarang Desa } \\
\text { Tumijaya merupakan desa pertama } \\
\text { yang mempunyai jenjang pendidikan } \\
\text { lengkap yang berbasis pesantren. } \\
\text { Bahkan Desa Tumijaya merupakan } \\
\text { desa satu-satunya dari semua desa } \\
\text { yang ada di Desa Tumijaya dimulai dari } \\
\text { jenjang taman kanak-kanak (TK), } \\
\text { kemudian madrasah ibtidaiyah (MI), } \\
\text { kemudian madrasah tsanawiyah (MTs), } \\
\text { kemudian madrasah aliyah (MA), dan } \\
\text { perguruan tinggi swasta yang baru } \\
\text { dibuka. Ini menandakan bahwa Desa } \\
\text { Tumijaya sudah mengalami } \\
\text { perkembangan dan kemajuan di } \\
\text { bidang pendidikan" }\end{array}$ \\
\hline
\end{tabular}

\section{Pembahasan}

\section{Nilai Budaya Menghormati Orang Lain}

Di Desa Tumijaya menghormati sesama manusia sangat banyak bentuknya.Terlihat dalam legenda ini sebuah penghormatan diberikan kepada almarhum mbah Tumi yang dulu merupakan tokoh pejuang desa. Nama Tumi dijadikan nama desa oleh seluruh masyarakat lewat musyawarah untuk menghormati segala jasa yang selama ini diberikan. Masyarakat sangat menghargai sosok almarhum mbah Tumi sebagai tokoh pejuang dan pendiri Desa Tumijaya mbah Tumi sudah mewujudkan cita-cita seluruh masyarakat, maka dari itu nama Desa Tumijaya dipilih sebagai bentuk penghormatan. Selain budaya menghormati orang lain yang tercermin dari sosok almarhum Mbah Tumi, nilai budaya menghormati orang lain saat ini yang bisa dilihat dan diterapkan oleh masyarakat sekitar di antaranya kebiasaan saling menghormati baik anak-anak menghormati yang remaja, remaja menghormati yang dewasa, dan yang dewasa menghormati yang tua.

\section{Keberagaman Agama}

Berikutnya nilai budaya menghormati agama orang lain dapat dilihat dari jumlah agama dan tempat peribadatan yang ada di Desa Tumijaya. Perbedaan akan keberagaman agama nyatanya bukan menjadi sebuah permasalahan bagi masyarakat yang hidup di desa tersebut. Terhitung ada 1939 kepala keluarga penduduk di Desa Tumijaya yang memeluk agama Islam, 204 kepala keluarga memeluk agama Kristiani, 7 kepala keluarga memeluk agama Hindu, 3 kepala keluarga memeluk agama Budha. Sedangkan tempat peribadatan untuk masjid sebanyak 2 buah, mushola 8 buah, dan gereja sebanyak 3 buah. 
Nilai budaya menghormati orang lain dapat dilihat dari keberagaman suku yang ada di Desa Tumijaya, hal tersebut bisa dilihat dari jumlah suku. Penduduk Desa Tumijaya dihuni bukan hanya dari satu suku saja melainkan banyak suku di antaranya suku Jawa, Batak, Ogan, dan Komering meskipun suku jawa di desa ini begitu dominan dianatara suku lain. Terhitung jumlah suku Jawa sebanyak 2089 kepala keluarga, jumlah suku Ogan sebanyak 30 kepala keluarga, jumlah suku Batak sebanyak 20 kepala keluarga, dan jumlah suku Komering sebanyak 11 kepala keluarga. Hal ini tentunya merupakan bentuk nilai tersediri yang dimiliki oleh penduduk Desa Tumijaya.

\section{Menghargai Keberagaman Bahasa}

Keberagaman bahasa yang dimiliki oleh penduduk Desa Tumijaya sangat banyak di antaranya ada bahasa Jawa, Ogan, Komering, dan Batak. Meskipun tidak dapat dipungkiri mayoritas penduduk Desa Tumijaya berbahasa Jawa, tetapi keberadaan keragaman tersebut justru membuat keharmonisan dalam masyarakat. Terhitung 90\% masyarakat Desa Tumijaya berbahasa Jawa, 3\% berbasa Batak, $2 \%$ berbahasa Komering, dan $5 \%$ berbahasa Ogan.

\section{Tanggung Jawab}

Tanggung jawab merupakan kesadaran diri manusia terhadap semua tingkah laku dan perbuatan yang disengaja.Nilai budaya rasa tanggung jawab digambarkan pada sosok almarhum mbah Ramso Joyo Kusumo dalam melanjutkan perjuangan untuk mewujudkan cita-cita bersama dulu ternyata membuahkan hasil.

\section{Kasih Sayang}

Mengasihi dan menyayangi dalam kehidupan perlu kita tanamkan, hal tersebut agar keharmonisan dan keutuhan bermasyarakat terjaga. Dapat dimengerti kesedihan yang dirasakan oleh seluruh penduduk desa yang kehilangan sosok almarhum mbah Tumi.

\section{Keberanian}

Keberanian sesorang cendrung dilihat dari kemampuannya untuk mengambil sebuah risiko yang muncul akibat dari keberanian tersebut nantinya akan mendapatkan sebuah hasil. Keberanian adalah sebuah proses yang menuju pada hasil, seperti pada keberanian almarhum mbah Tumi dalam menyelesaikan permasalahan.

\section{Cinta Tanah Air}

Mencintai tanah air mempunyai arti kita harus menjaga keutuhan, persatuan, dan hak milik. Rela melakukan apa saja demi tanah air yang kita tinggali, hal tersebut bisa kita temukan nilai budaya cinta tanah air dalam upaya yang dilakukan almarhum mbah Tumi dan penduduk untuk memenuhi syarat-syarat yang diminta untuk pemekaran.

\section{Pendidikan}

Pendidikan merupakan hal penting yang harus ditempuh setiap individu, dengan pendidikan manusia akan dimanusiakan oleh yang lain. Dalam legenda Desa Tumijaya ini dikatakan semenjak berhasil dimekarkan pada tahun 1999 sampai sekarang ini sudah terpenuhi jenjang pendidikan dari dasar sampai jenjang pendidikan tertinggi.

\section{PENUTUP}

Berdasarkan hasil penelitian dan pembahasan data di atas, peneliti memperoleh kesimpulan yang dapat diambil mengenai "Nilai Budaya dalam Cerita Legenda Desa Tumijaya Kecamatan Jayapura Syaiful Anam,Sugiarti, Shakti Apdilah Pratama 
Kabupaten OKU Timur". Cerita legenda tersebut memang terdapat nilai budaya di antaranya nilai budaya tentang pentingnya menghormati orang lain, nilai budaya tentang pentingnya menghormati keberagaman suku, nilai budaya tentang pentingnya menghormati keberagaman bahasa, nilai budaya tentang rasa tanggung jawab, nilai budaya tentang kasih sayang, nilai budaya tentang keberanian, nilai budaya tentang cinta tanah air, dan nilai budaya tentang pendidikan.

\section{UCAPAN TERIMAKASIH}

Ucapan terima kasih ditujukan kepada ketua STKIP Nurul Huda, ketua LPPM Nurul Huda, dan TIM penelitian yang telah berupaya sekuat tenaga demi kesuksesan penelitian ini.

\section{DAFTAR PUSTAKA}

Danandjaja, J. 2002. Folklor Indonesia: IImu Gosip, Dongeng dan lain-lain. Pustaka Utama Grafiti.

Lisa Krisdayani Sitepu, Maria Natalia Situmorang, Wita Dewi, S. D. B. G. 2019. Eksplorasi Legenda Selang Pangeran sebagai Bahan Ajar Bahasa Indonesia. BASA TAKA, 2.

Maesaroh, S. 2013. Peranan Metode Pembelajaran Terhadap Minat dan Prestasi Belajar Pendidikan Agama Islam. Jurnal Kependidikan, 1.

Spradley, J. A. 2006. Metode Etnografi. Terjemahan Mizbah Zulfa Elizabeth. Tiara Wacana.

Sugiyono. 2008. Metode Penelitian Bisnis. Alfabeta.

Sugiyono. 2018. Metode Penelitian Kuantitatif, Kualitatif, dan R\&D. Alfabeta. 